\title{
RESEARCH OF MAXIMUM STRESS ZONES IN CIRCULAR PLATES WITH LOADES CONCENTRATED FORCE
}

\author{
KONIECZNY Mateusz ${ }^{*}$, ACHTELIK Henryk ${ }^{2}$, GASIAK Grzegorz ${ }^{3}$ \\ ${ }^{I}$ Opole University of Technology, Faculty of Mechanical Engineering, Department of Mechanics and Machine \\ Design, St. Mikołajczyka 5, 45-271 Opole, Poland, e-mail: mateuszmarcinkonieczny@wp.pl \\ ${ }^{2}$ Opole University of Technology, Faculty of Mechanical Engineering, Department of Mechanics and Machine \\ Design, St. Mikotajczyka 5, 45-271 Opole, Poland \\ ${ }^{3}$ Opole University of Technology, Faculty of Mechanical Engineering, Department of Mechanics and Machine \\ Design, St. Mikołajczyka 5, 45 - 271 Opole, Poland, e-mail: g.gasiak@po.edu.pl
}

\begin{abstract}
The paper presents numerical and experimental analysis of the state of stress in a circular perforated plate, free supported or fixed on entire premier and loaded concentrated force. This type of plate have found applications in the field of chemical equipment, pressure tanks and box conveyors. The use of the finite element method for numerical calculations enables accurate location of stress concentration zones in a perforated plate and allows to determine stress values around these hole.
\end{abstract}

KEYWORDS: Perforated plate, reduced stresses, numerical calculations, experimental research

\section{Introduction}

Present engineering constructions are characterized by a decrease of the safety factor, which is why calculations of strength, stiffness and stability of thin-walled construction elements are becoming some of the important aspects in all branches of technology, especially such as chemical engineering. There are many applications of perforated plates e.g. in pressure vessels, chemical equipment (heat exchanger tube screens) [1], oil refineries, box conveyors [2] or as elements of loose material screens, which can be subjected to a load that varies over time. This type of girders (perforated plates) can also act as mounting plates in which holes are made for various operational reasons $[3,4]$.

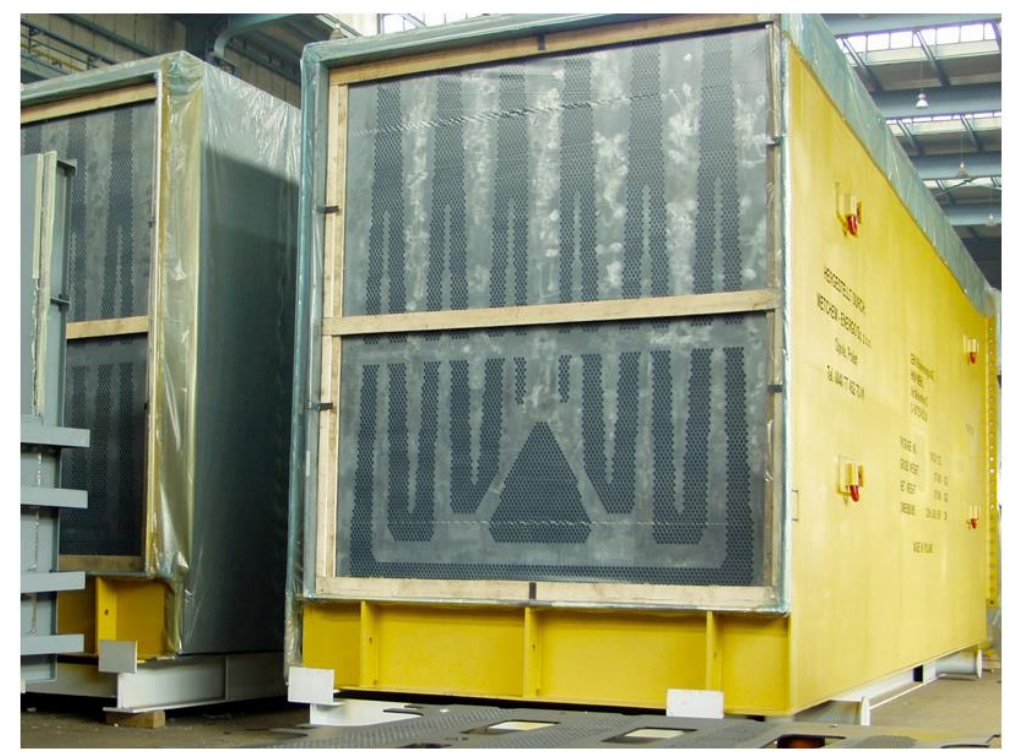

Fig. 1 Box conveyors [2] 
In practical design issues, it is often necessary to determine stresses and deflections in such plates, which are loaded with static forces acting perpendicular to their surface. Due to the wide application of perforated elements in many branches of industry, it is advisable to undertake studies involving the analysis of the state of stress regarding such elements subjected to a normal load. Knowledge of the state of stress will offer optimal design; and thus, safe operation of devices in which these types of components are used has been made more feasible $[5,6,7,8,9]$.

In literature, many attempts were made to analyze stress concentration, deflections, strains, stress concentration factor and stress intensity factor in perforated plates weakened because of openings in them. The analytical method $[10,11]$, the experimental method $[12,13]$ and the numerical method $[14,15,16,17,18,19,20,21]$ were used to evaluate the parameters of perforated plates. In the work [12], the authors developed a methodology of experimental research that which allow to determine the stresses histories in perforated plates centrally loaded by a concentrated force. The diameter of the holes, as well as the geometry of their distribution in the plate prepared for the study, provided for the constancy of section-weakening coefficients. Resistance strain gauges were placed between the holes in order to measure the strains. The axially symmetric perforated plate was subjected to bending with a concentrated force applied centrally. On the basis of the measured values of the strain, radial, circumferential and equivalent stresses in the plate were determined. The experimental research corroborated the correctness of the adopted model of calculating the stress states in the perforated plate. However, in the work [22], optimum hole size and shape of perforated plates with round and staggered holes investigated using mid-point deflections of perforated plates under their selfweights. Analysed plates are free supported on their four sides. The ANSYS program was used for research. The square perforated plates were examined in terms of mid-point deflections by changing numbers, radii and locations or their holes. The results obtained can be useful for determine the design parameters and perforation operations of perforated square plates with round and staggered holes.

The purpose of the study reported in the present paper is to locate the zones in which maximum stresses occur in a circular axisymmetric perforated plate, free supported or fixed and loaded with concentrated force $P_{i}$ applied in the geometric center of the plate. Tests of stress concentration zones were performed numerically using the finite element method.

\section{Model and material of the perforated plate}

The calculation was based on a circular axisymmetric perforated plate with the dimensions: diameter $D=300 \mathrm{~mm}$, thickness $h=5 \mathrm{~mm}$. 200 holes with different radii placed on the plate. These holes were arranged in 10 circles with 20 holes in each circle, as shown in Figure 2. As a plate material, S235JR steel sheet with the following mechanical parameters was adopted: $E$ $=205 \mathrm{GPa}$, Poisson's ratio $v=0.3$. In the first variant, the perforated plate was free supported (Fig. 3a) over the entire perimeter and loaded with concentrated force $P_{i}$ applied in the geometric center of the plate, and in the second variant the perforated plate was fixed (Fig. 3b) over the entire perimeter and loaded with concentrated force $P_{i}$ applied in the geometric center of the plate (Fig 3). The following values of the load were assumed $P_{i}: P_{1}=410 \mathrm{~N} ; P_{2}=875$

$\mathrm{N} ; P_{3}=1365 \mathrm{~N} ; P_{4}=1925 \mathrm{~N} ; P_{5}=2510 \mathrm{~N}$. With two variants on the axisymmetric perforated plate, ten measurement zones were marked, i.e. from Z1 to Z10 (Fig. 2). 


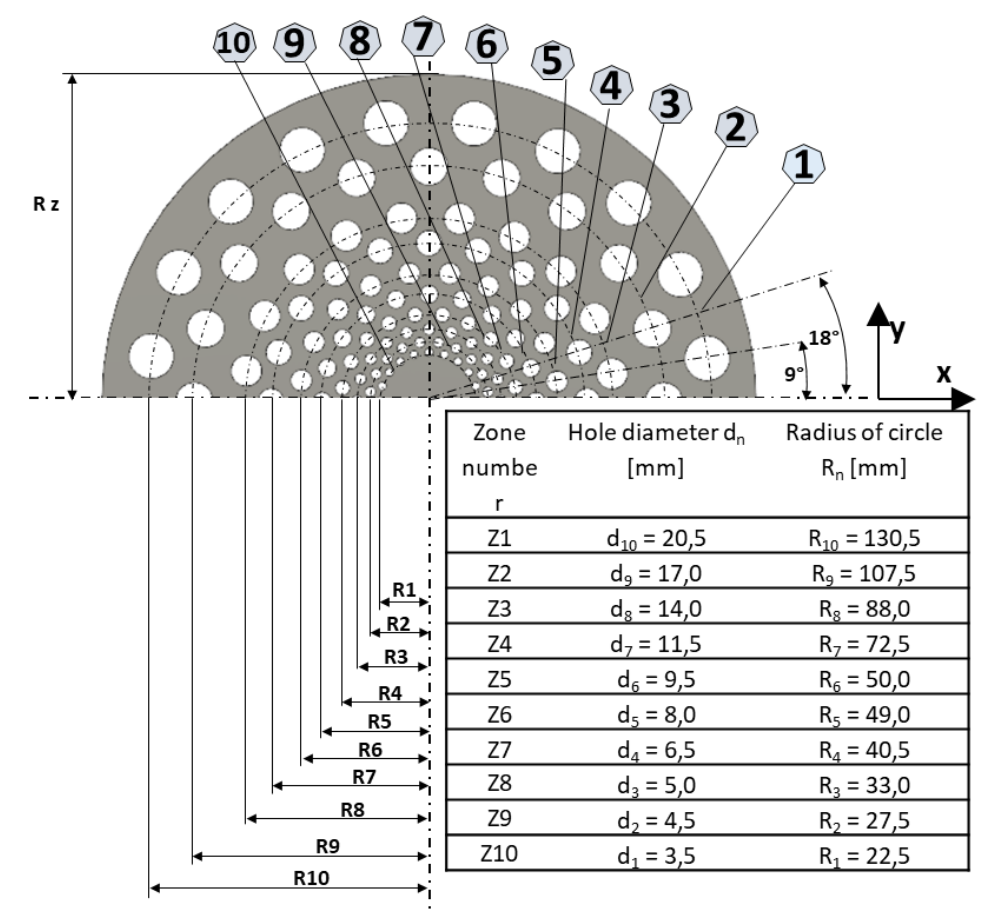

Fig. 2 Model of perforated plate with ten measuring zones, i.e. from Z1 to Z10 [12]

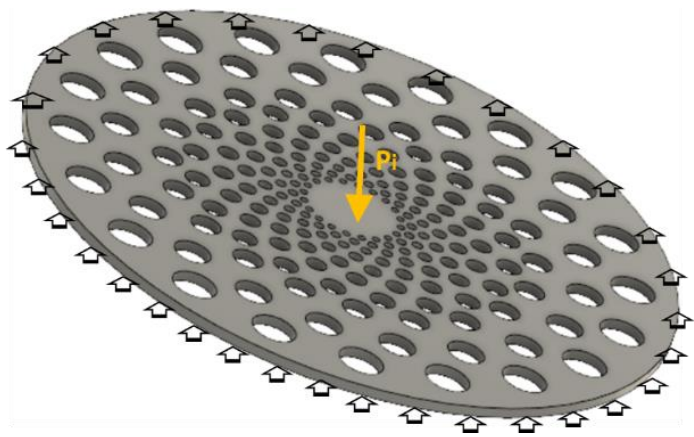

a)

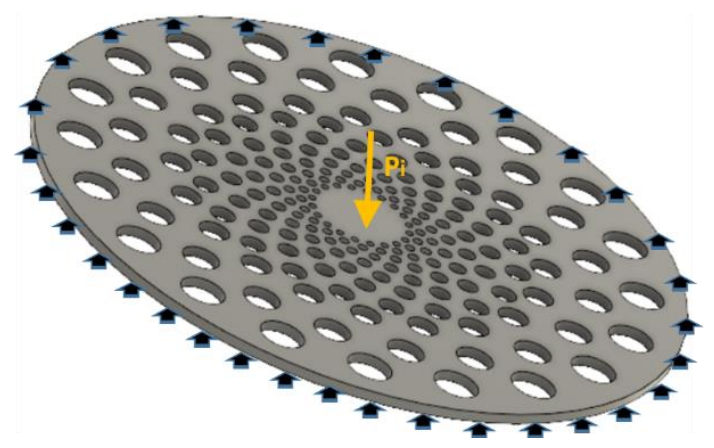

b)

Fig. 3 A circular axisymmetric perforated plate loaded with concentrated force $P_{i}$ applied in the geometric center of the plate with the following boundary conditions: a) free supported over the entire perimeter; b) fixed over the entire perimeter

\section{Numerical calculation}

The subject of numerical calculations of the state of stress applied a circular axisymmetric perforated plate, which geometry, i.e. the dimension, the method of restraint and the load method were outlined in section 2 of this paper. Numerical calculations were carried out using the ANSYS program [23]. ANSYS is a program for numerical calculations using the finite element method (FEM). It allows solving complex tasks with high accuracy. ANSYS uses a range of advanced and universal technologies that enable quick, efficient and simple preparation of the calculation model.

The plate solid was modelled using cubic spatial finite elements (3D) with square sides containing twenty nodes (eight nodes in the corners and twelve on the edges of the element sides), i.e. W20, described by a square shape function (Figures 4 and 5). The computational model contained the total number of finite elements 130620, while the total number of nodes was 596310. The plate solid had 6 layers of finite elements. 


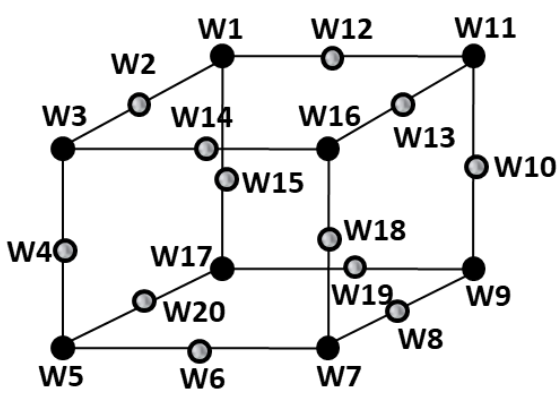

a)

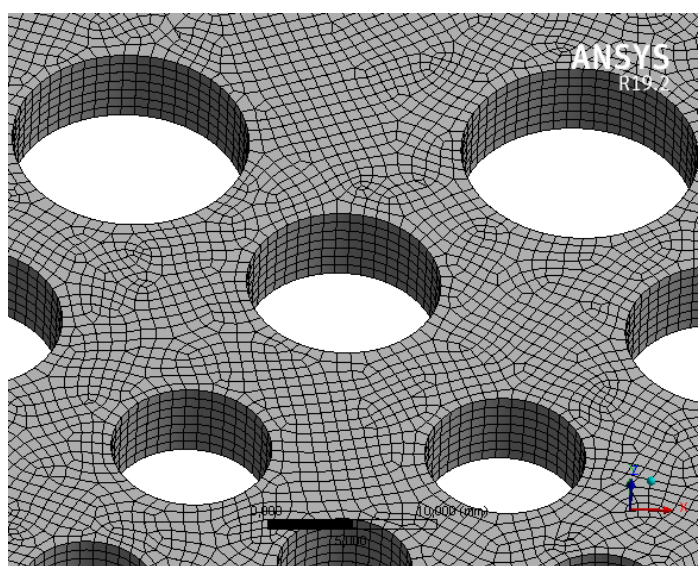

b)

Fig. 4 a) A cubic spatial element (3D) with a square shape function with twenty nodes, i.e. from W1 to W20; b) Division of the plate into finite elements

For example, in Fig. 5, the distribution of reduced stresses $\sigma_{\text {red }}$ is given, calculated according to the von Misses hypothesis in a circular axisymmetrical perforated plate, free supported and loaded with concentrated force $P_{i}$ applied in the geometric center of the plate with the value $P_{5}$ $=2510 \mathrm{~N}$.
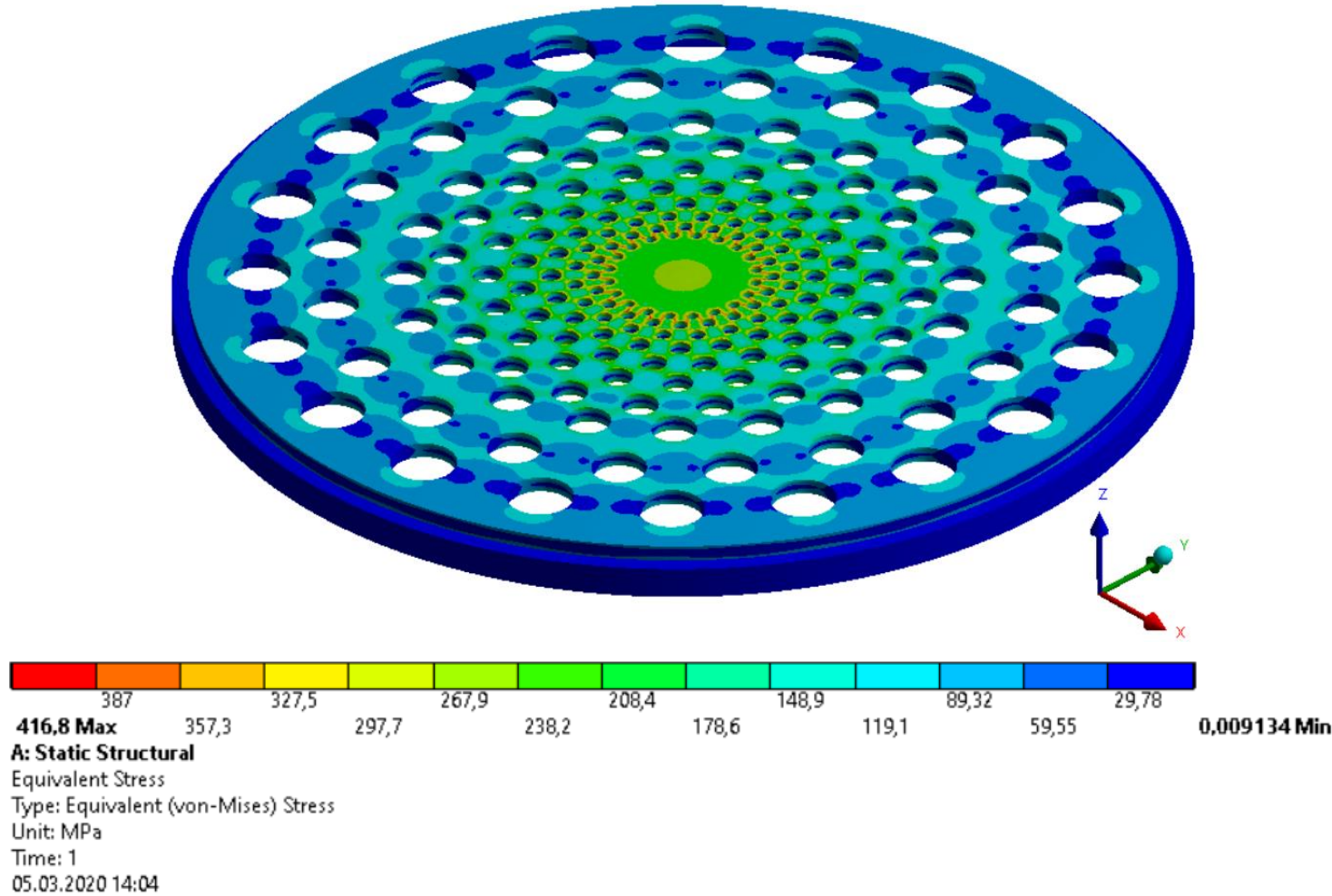

Fig. 5 Distribution of reduced stress $\sigma_{\text {red }}$ given in MPa for an axisymmetric perforated plate free supported and loaded with concentrated force $P_{i}$ applied in the geometric center of the plate with the value $P_{5}=2510 \mathrm{~N}, \sigma_{\text {red } \max }=416.79 \mathrm{MPa}$

However, the location of stress concentration zones in the tested plate is shown in Figure 6. The figure illustrates the distribution of reduced stresses given in $\mathrm{MPa}$ in two sample measuring zones (in the first zone $\mathrm{Z} 1$ - the closest to the edge of the plate and in the tenth zone $\mathrm{Z10}$ - the 
closest to the central part of the plate), (Fig. 2). Points T1 and T10 define the values of reduced stresses obtained numerically at control measuring points, and P1 and P10 are points of identification of the maximum numerical values of stress. In square brackets the values of three coordinates, i.e. $\mathrm{x}, \mathrm{y}, \mathrm{z}$ coordinates, are given.

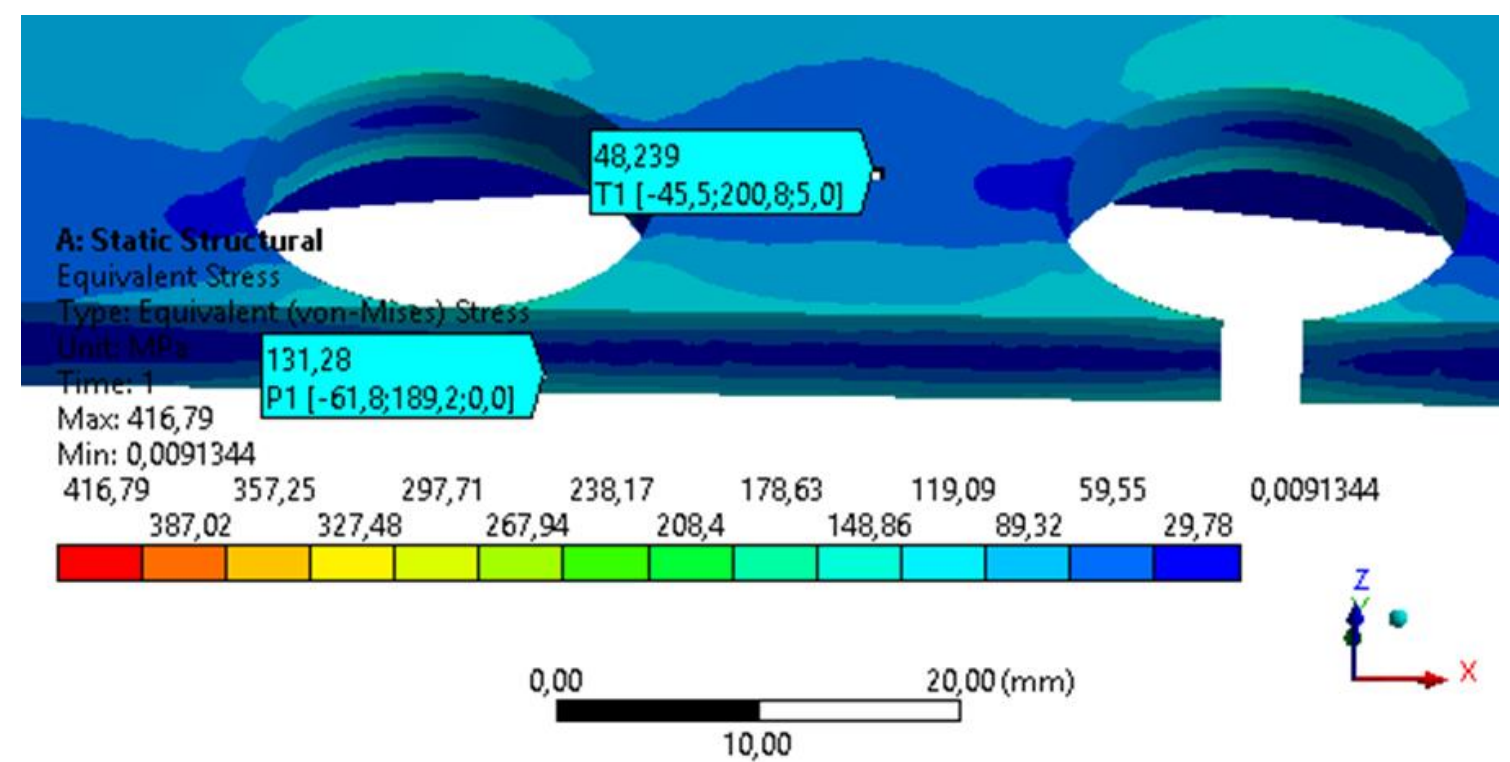

a)

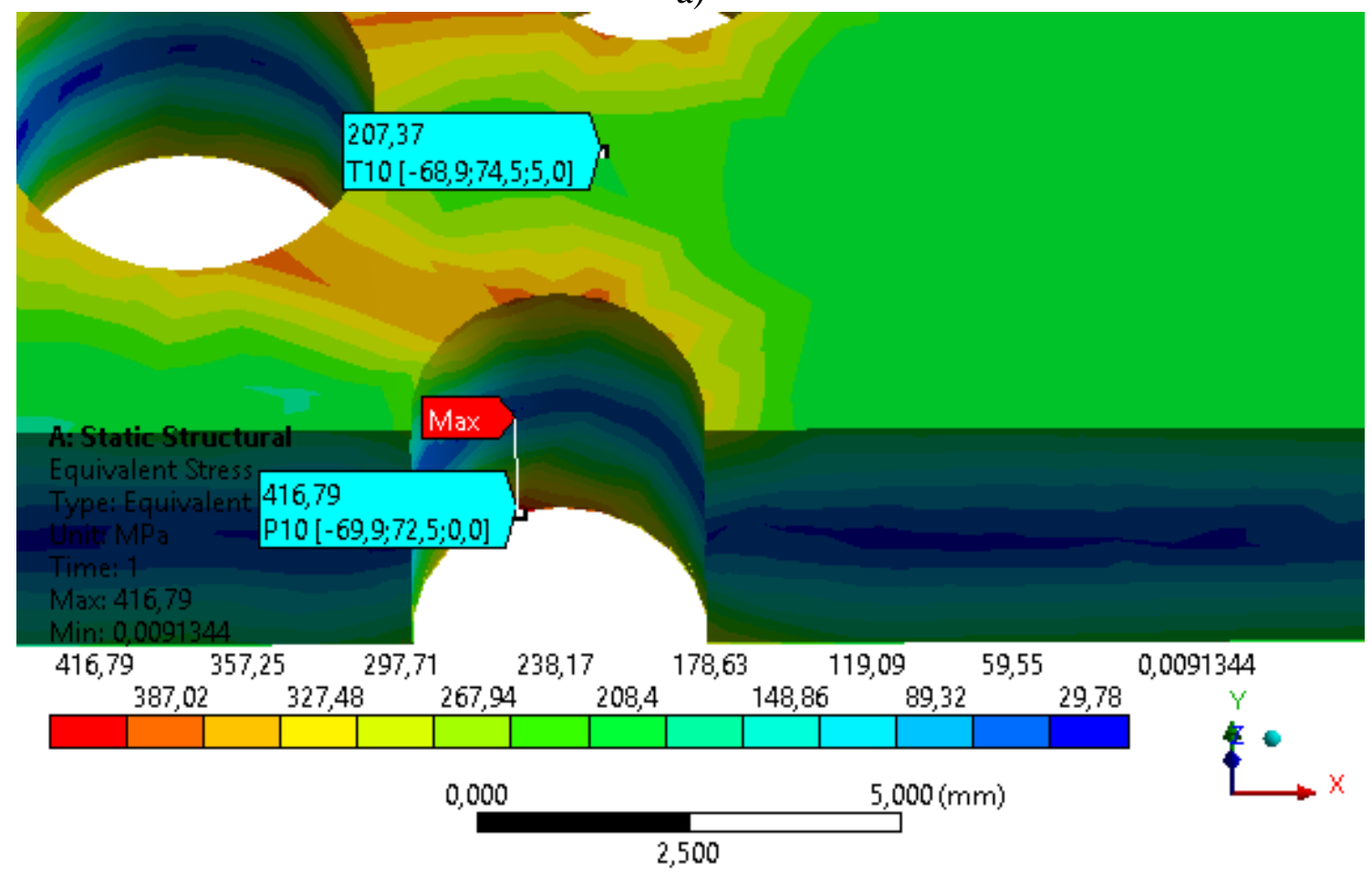

b)

Fig. 6 Reduction stress zones $\sigma_{\text {red }}$ given in MPa for an axisymmetric perforated plate free supported and loaded with concentrated force $P_{i}$ applied in the geometric center of the plate with the value $P_{5}=2510 \mathrm{~N}$ : a) zone Z1: $\left.\sigma_{\text {red } \max }=131.28 \mathrm{MPa} ; \mathrm{b}\right)$ zone Z10: $\sigma_{\text {red } \max }=416.79$ $\mathrm{MPa}$ 
For example, in Fig. 7, the distribution of reduced stresses $\sigma_{\text {red }}$ is given, calculated according to the von Misses hypothesis in a circular axisymmetrical perforated plate, fixed and loaded with concentrated force $P_{i}$ applied in the geometric center of the plate with the value $P_{5}=2510$ N.
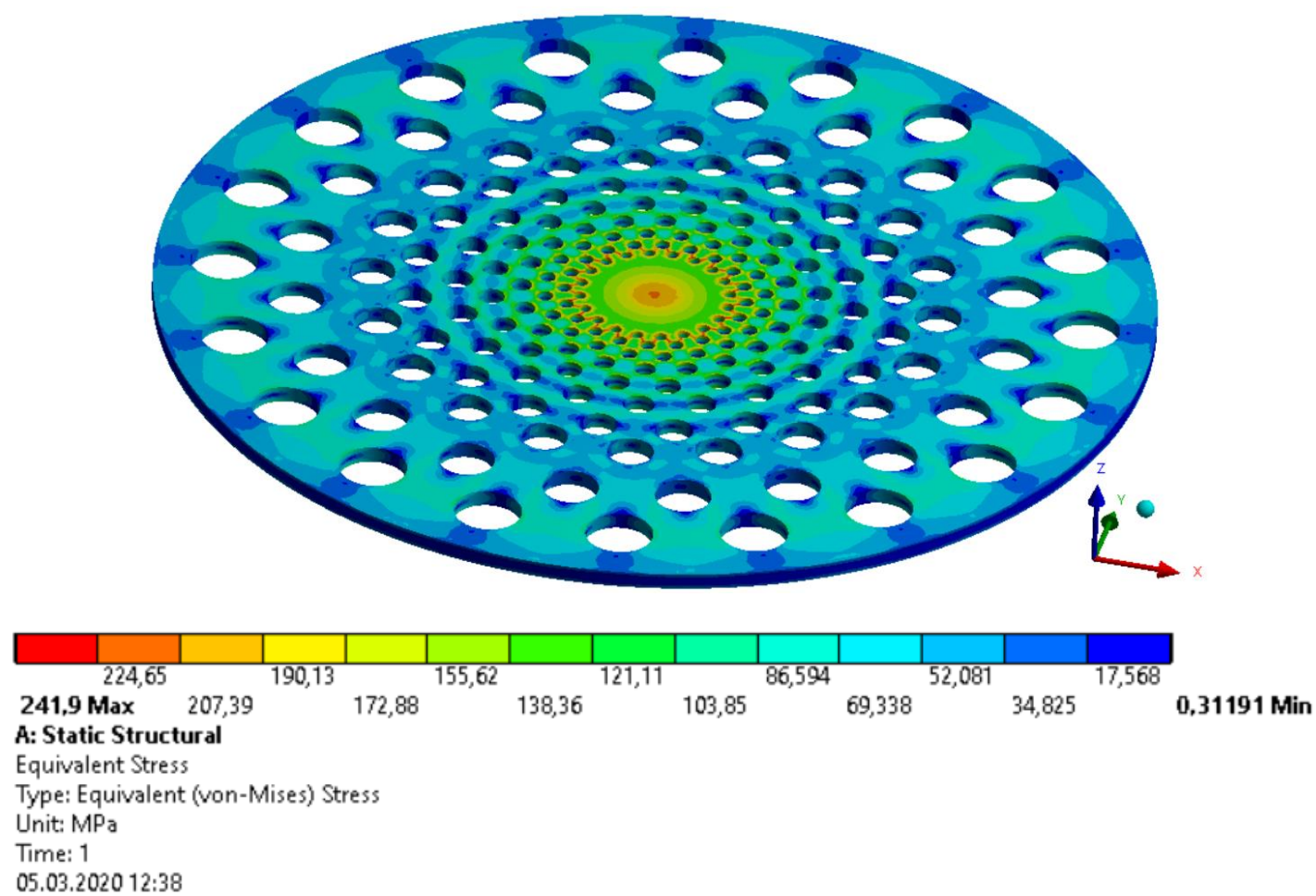

Fig. 7 Distribution of reduced stress $\sigma_{\text {red }}$ given in MPa for an axisymmetric perforated plate fixed and loaded with concentrated force $P_{i}$ applied in the geometric center of the plate with the value $P_{5}=2510 \mathrm{~N}, \sigma_{\text {red } \max }=241.9 \mathrm{MPa}$

However, the location of stress concentration zones in the tested plate is shown in Figure 8. The figure illustrates the distribution of reduced stresses given in $\mathrm{MPa}$ in two sample measuring zones (in the first zone Z1 - the closest to the edge of the plate and in the tenth zone Z10 - the closest to the central part of the plate), (Fig. 2). Points T1 and T10 define the values of reduced stresses obtained numerically at control measuring points, and P1 and P10 are points of identification of the maximum numerical values of stress. In square brackets the values of three coordinates, i.e. $\mathrm{x}, \mathrm{y}, \mathrm{z}$ coordinates, are given. 


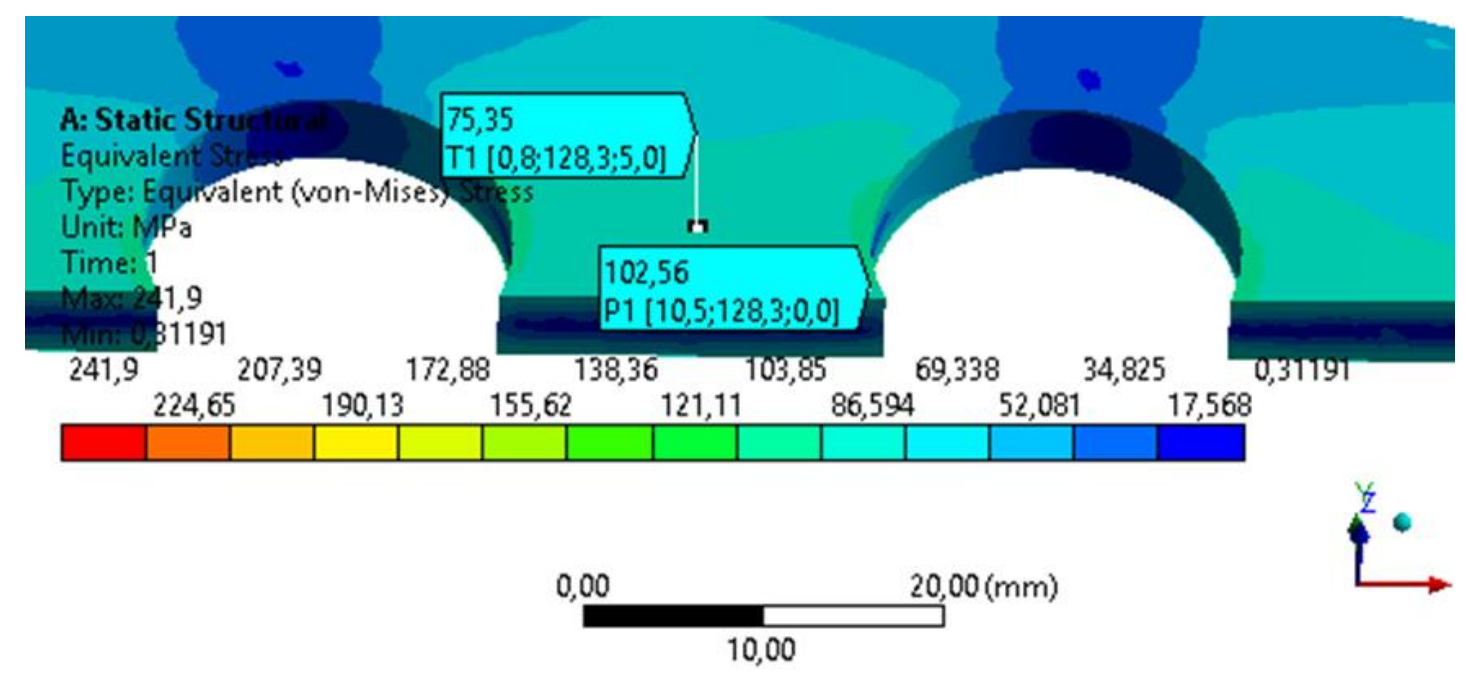

a)

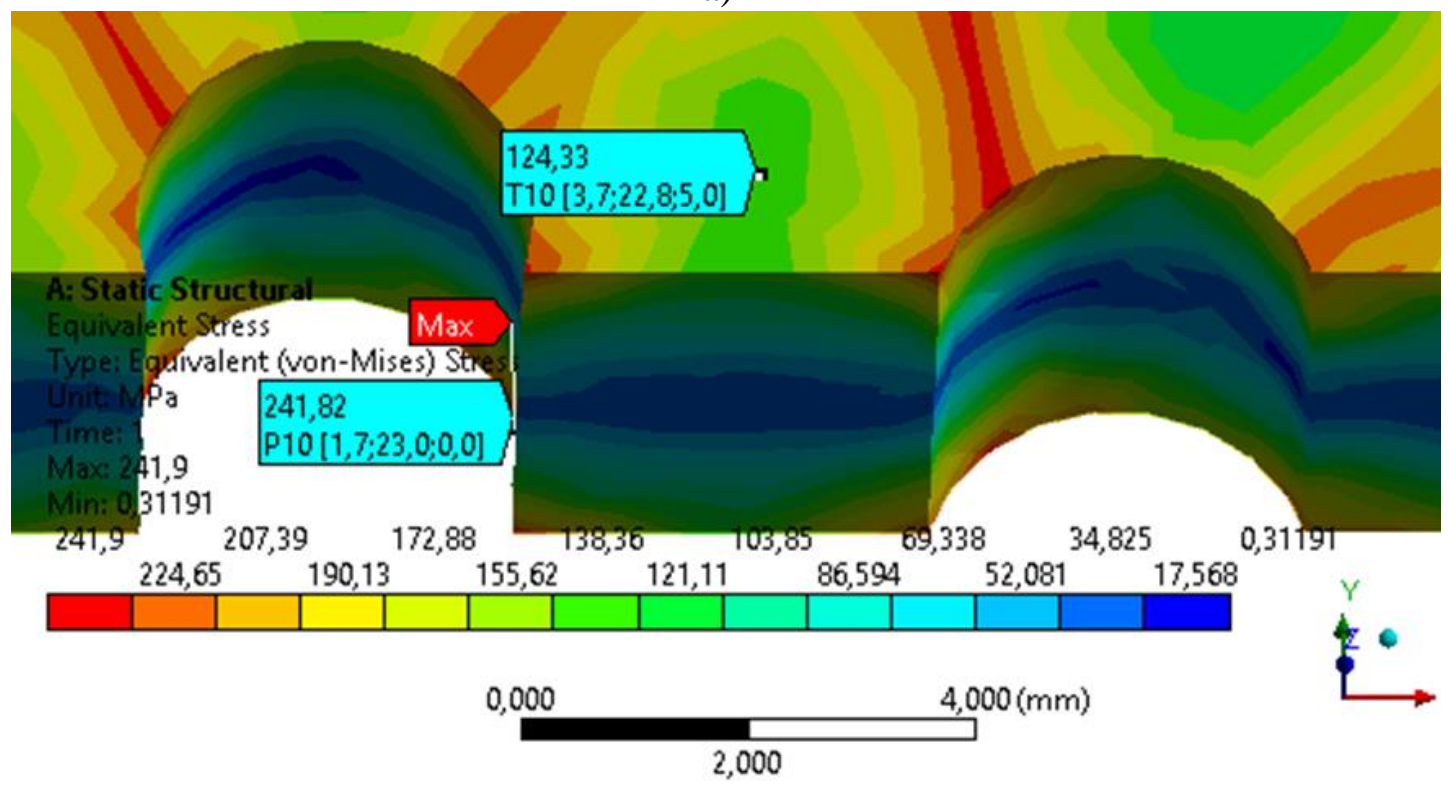

b)

Fig. 8 Reduction stress zones $\sigma_{\text {red }}$ given in MPa for an axisymmetric perforated plate fixed and loaded with concentrated force $P_{i}$ applied in the geometric center of the plate with the value $P_{5}=2510 \mathrm{~N}$ : a) zone $\mathrm{Z} 1: \sigma_{\text {red } \max }=102.56 \mathrm{MPa}$; b) zone Z10: $\sigma_{\text {red } \max }=241.9 \mathrm{MPa}$

\section{Experimental research}

The aim of experimental research was to verify, i.e. assess the accuracy associated with solving a given design with respect to its strength. The basis for such an evaluation involves the study of the effect exerted on the material defined by stress and strain states in the considered structural elements. Both real objects and their models made of different materials can be used to test these states. As a result of these tests, it is possible to verify the results derived numerically.

The subject of the experimental research of the state of stress was a circular axisymmetric perforated plate, which geometry, i.e. the dimension, the method of restraint and the load method were outlined in section 2 of this paper. The strain gauges were stuck on the previously prepared plate surface at the points shown in Figure 9. Foil strain gauges type TF - 1/120, TFW $-2 / 120, \mathrm{TF}_{\mathrm{P}}-2 / 120$ were used for the measurement of strains in the perforated plate. For 
practical reasons, the strain gauges were placed in eight circles, meaning with radii $R_{3}, R_{4}, \ldots$, $\mathrm{R}_{10}$. Since the tested perforated plate was axially symmetric, the strain gauges were placed in the first and fourth quarter as shown in Figure 9.

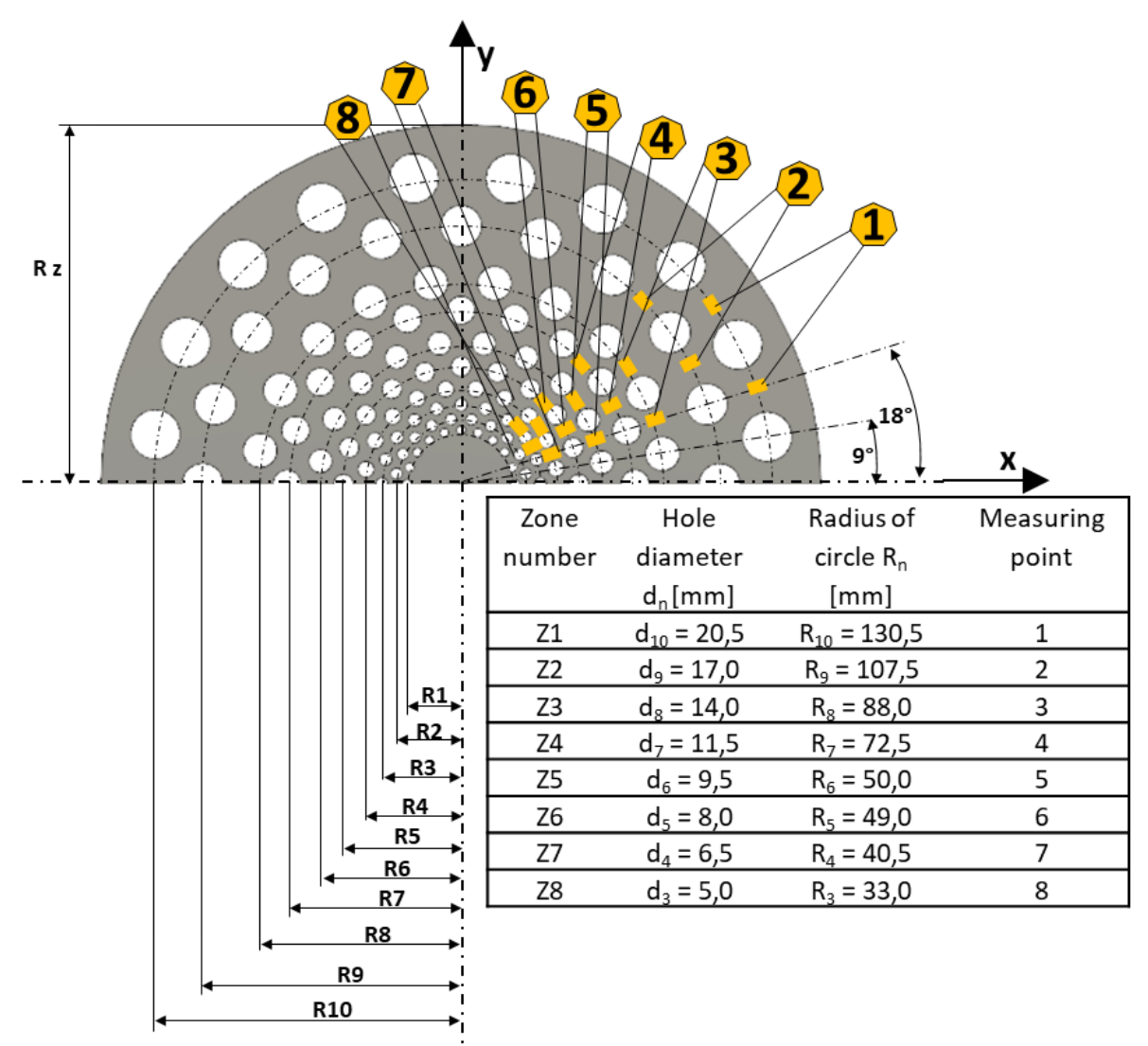

Fig. 9 The arrangement of extensometers on a circular axisymmetric perforated plate schematically (numbered 1-8) [12]

The perforated plate with the collocated strain gauges was subsequently mounted on a suitable annular support, concentric in relation to the loading mandrel of the strength test stand. A schematic of the plate mounting and the applied concentric load application $P$ are shown in figure 10. In order to control the plate deflection, a dial gauge was used with an accuracy of $0.001 \mathrm{~mm}$. The gauge was installed so that the axis of the gauge plunger coincided with the axis of the loading mandrel [9].

During the first stage of the study, a preload $\mathrm{P}_{0}$ was applied to the perforated plate. This caused a preliminary deflection in the plate center, $\mathrm{f}_{0}=1 \mathrm{~mm}$. This deflection corresponded to the force $\mathrm{P}_{0}=570 \mathrm{~N}$. Having obtained the preliminary loading and deflection, the readings of the strain gauges were taken in each measuring region in radial and circumferential directions. Next, the plate was loaded with a force $P_{i}$, which caused the deflection $f_{i}=1.5 \mathrm{~mm}$. The readings of the strain gauge were taken again and they were marked with the index " $\mathrm{k}$ " standing for the "final readings". The value of force $P_{n}$ and the ensuing deflection $f_{n}$ were calculated from the relations:

$$
\begin{gathered}
P_{n}=P_{i}-P_{0}, \\
f_{n}=f_{i}-f_{0},
\end{gathered}
$$

where: $\mathrm{n}$ - successive natural numbers, i.e. $1,2,3,4,5 ; \mathrm{i}=I, I I, I I I, I V, V$. 


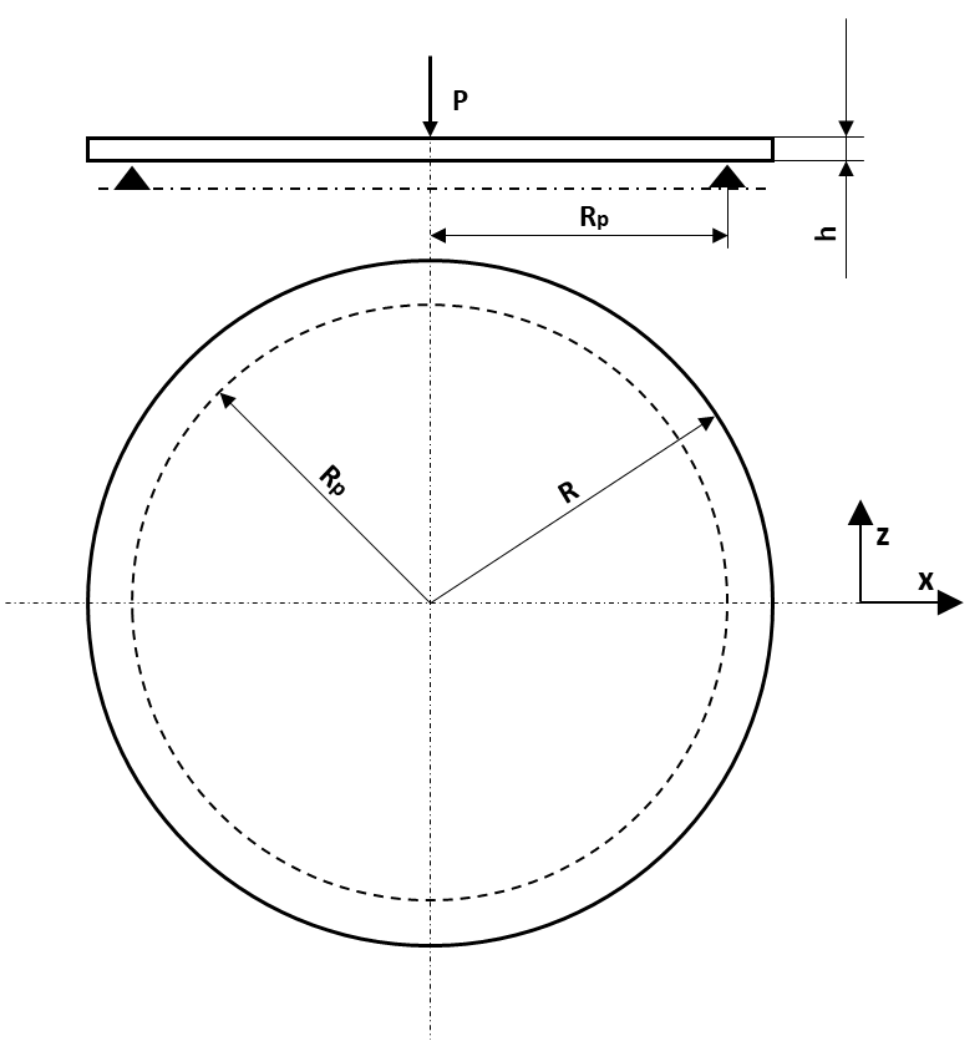

Fig. 10 A scheme of support of a circular axisymmetric perforated plate loaded with concentrated force $P_{i}$ applied in the geometric center of the plate, where $R_{p}$ - radius of supports distribution, $\mathrm{h}$ - plate thickness [12]

The successive loads applied by forces: $P_{I}, P_{I I}, P_{I I I}, P_{I V}, P_{V}$ were used so as to obtain deflections equal to $f_{I I}=2 \mathrm{~mm}, f_{I I I}=2.5 \mathrm{~mm}, f_{I V}=3 \mathrm{~mm}, f_{V}=3.5 \mathrm{~mm}$, respectively. In this case, loading values were $P_{I}=410 \mathrm{~N}, P_{I I}=875 \mathrm{~N}, P_{I I I}=1365 \mathrm{~N}, P_{I V}=1925 \mathrm{~N}, P_{V}=2510 \mathrm{~N}$. The deformations of the perforated plate subjected to the above loadings were measured in the radial and circumferential directions, at points along the $\mathrm{x}$ - and $\mathrm{y}$-axes. Finally, the strain gauge readings and the calculated radial and circumferential strains, $\varepsilon_{\mathrm{r}}$ and $\varepsilon_{\theta}$, were used for the determination of the radial stresses $\sigma_{r}$ and circumferential stresses $\sigma_{\Theta}$ in the investigated perforated plate.

It was assumed that in the tested perforated plate, a plane stress state occurs. Having determined empirically the strains $\varepsilon_{r}$ and $\varepsilon_{\theta}$ the principal stress components in the radial and circumferential directions, $\sigma_{r}$ and $\sigma_{\theta}$, were defined on the basis of the following relations [24]:

$$
\begin{aligned}
\sigma_{\theta} & =\frac{E}{1-v^{2}}\left(\varepsilon_{\theta}+v \varepsilon_{r}\right), \\
\sigma_{r} & =\frac{E}{1-v^{2}}\left(\varepsilon_{r}+v \varepsilon_{\theta}\right),
\end{aligned}
$$

The reduced stress was determined using the relations:

$$
\sigma_{\text {red }}=\sqrt{\sigma_{r}^{2}+\sigma_{\theta}^{2}-\sigma_{r} \sigma_{\theta}}
$$




\section{Results of the research}

Based on numerical calculations using the finite element method (FEM) and experimental research, the results that were obtained could be compared. Table 1 presents the values of reduced stresses $\sigma_{\text {red }}$ in the zones of accumulated stresses for a circular axisymmetric perforated plate, free supported and loaded with concentrated force $P_{i}$ applied in the geometric center of the plate, numerically and experimentally determined in eight measuring points and the difference between the results obtained methods $\delta \sigma_{\text {red }}$.

Table 1 The values of reduced stresses $\sigma_{\text {red }}$ numerically and experimentally determined.

\begin{tabular}{|c|c|c|c|c|c|c|c|c|c|}
\hline \multirow{2}{*}{$\begin{array}{c}P_{i} \\
{[\mathbf{N}]}\end{array}$} & \multirow[t]{2}{*}{$\sigma \quad$ [MPa] } & \multicolumn{8}{|c|}{$\boldsymbol{R}_{n}[\mathrm{~mm}]$} \\
\hline & & 33,0 & 40,5 & 49,0 & 60,0 & 72,5 & 88,0 & 107,5 & 130,5 \\
\hline \multirow{3}{*}{410} & $\sigma_{\text {red }}^{n}$ & 26.25 & 22.62 & 18.61 & 15.31 & 13.67 & 10.54 & 9.39 & 7.87 \\
\hline & $\sigma_{\text {red }}^{e}$ & 34.17 & 28.84 & 23.92 & 18.68 & 17.59 & 12.07 & 8.63 & 5.32 \\
\hline & ${ }^{*} \delta \sigma_{\text {red }} \%$ & -30.17 & -27.50 & -28.53 & -22.01 & -28.68 & -14.52 & 8.09 & 32.40 \\
\hline \multirow{3}{*}{875} & $\sigma_{\text {red }}^{n}$ & 56.03 & 48.29 & 39.72 & 32.66 & 29.18 & 22.50 & 20.06 & 16,82 \\
\hline & $\sigma_{\text {red }}^{e}$ & 72.07 & 60.31 & 50.71 & 39.25 & 33.71 & 25.37 & 17.97 & 12.62 \\
\hline & ${ }^{*} \delta \sigma_{\text {red }} \%$ & -28.63 & -24.89 & -27.67 & -20.48 & -15.52 & -12.76 & 10.42 & 24.97 \\
\hline \multirow{3}{*}{1365} & $\sigma_{r e d}^{n}$ & 87.41 & 75.33 & 61.96 & 50.96 & 45.52 & 35.10 & 32.29 & 26.23 \\
\hline & $\sigma_{\text {red }}^{e}$ & 102,25 & 88,09 & 17,96 & 59.22 & 47.27 & 37.02 & 27.73 & 18.65 \\
\hline & ${ }^{*} \delta \sigma_{\text {red }} \%$ & -16.98 & -16.94 & -16.14 & -16.21 & -3.84 & -5.47 & 14.12 & 28.90 \\
\hline \multirow{3}{*}{1925} & $\sigma_{\text {red }}^{n}$ & 123.28 & 106,23 & 87.38 & 71.86 & 64.19 & 49.51 & 44.13 & 37.00 \\
\hline & $\sigma_{\text {red }}^{e}$ & 131.18 & 113.22 & 93.26 & 75.45 & 58.42 & 47.79 & 38.79 & 27.40 \\
\hline & ${ }^{*} \delta \sigma_{\text {red }} \%$ & -6.41 & -6.58 & -6.73 & -2.00 & 8.99 & 3.47 & 12.10 & 25.95 \\
\hline \multirow{3}{*}{2510} & $\sigma_{\text {red }}^{n}$ & 160.74 & 138.51 & 113.93 & 93.97 & 83.70 & 64.55 & 57.54 & 48.24 \\
\hline & $\sigma_{r e d}^{e}$ & 160,03 & 138.62 & 114.62 & 93.18 & 73.17 & 59.52 & 55.62 & 36.14 \\
\hline & ${ }^{*} \delta \sigma_{\text {red }} \%$ & 0.44 & -0.08 & -061 & 0.55 & 12.58 & 7.79 & 3.34 & 25.08 \\
\hline \multicolumn{10}{|c|}{ *) $\delta \sigma_{\text {red }}=\frac{\sigma_{\text {red }}^{n}-\sigma_{\text {red }}^{e}}{\sigma_{\text {red }}^{n}} * 100 \%$} \\
\hline
\end{tabular}

In the case of a circular axisymmetrical perforated plate, free supported and loaded with concentrated force $P_{i}$ applied in the geometric center of the plate, the obtained results of calculations indicate that the highest value of reduced stress $\sigma_{\text {red }}$ at control measuring points occurred when the perforated plate was loaded with a concentrated force $P_{i}$ with the value $P_{5}=$ $2510 \mathrm{~N}$, both in the case of experimental calculations, as well as numerical calculations, which was $\sigma_{\text {red }}^{e}=160.03 \mathrm{MPa}$ and $\sigma_{\text {red }}^{n}=160.74 \mathrm{MPa}$ (Tab, 1). The relative difference, in this case, was $0.44 \%$. Comparison of all results obtained experimentally with numerically calculated results showed that the maximum calculation error was less than 33\%. It follows from the above that the numerical results obtained by the finite element method (FEM) for the case of perforated plates can be considered sufficiently accurate for engineering calculations.

Based on numerical calculations using the finite element method (FEM), the results that were obtained could be compared. Table 2 presents the values of reduced stresses $\sigma_{\text {red }}$ in the zones of accumulated stresses for a circular axisymmetric perforated plate, free supported $\sigma_{\text {red }}^{S}$ or fixed $\sigma_{\text {red }}^{F}$ and a percentage difference between results obtained for these cases $\delta \sigma_{\text {red }}$ and loaded with concentrated force $P_{i}$ applied in the geometric center of the plate. 
Table 2 The values of reduced stresses $\sigma_{\text {red }}$ numerically determined.

\begin{tabular}{|c|c|c|c|c|c|c|c|c|c|c|c|}
\hline \multirow{2}{*}{$\begin{array}{c}P_{i} \\
{[\mathbf{N}]} \\
\end{array}$} & \multirow[t]{2}{*}{$\sigma[\mathrm{MPa}]$} & \multicolumn{10}{|c|}{$\boldsymbol{R}_{n}[\mathrm{~mm}]$} \\
\hline & & 22,5 & 27,5 & 33,0 & 40,5 & 49,0 & 60,0 & 72,5 & 88,0 & 107,5 & 130,5 \\
\hline \multirow{3}{*}{410} & $\sigma_{r e d}^{S}$ & 33.87 & 32.83 & 26.25 & 22.62 & 18.61 & 15.31 & 13.67 & 10.54 & 9.39 & 7.87 \\
\hline & $\sigma_{r e d}^{F}$ & 20.31 & 18.65 & 13.68 & 10.19 & 7.16 & 5.82 & 6.42 & 7.28 & 10.05 & 12.31 \\
\hline & ${ }^{*} \delta \sigma_{\text {red }} \%$ & 40.04 & 43.19 & 47.85 & 54.95 & 61.53 & 61.99 & 53.04 & 30.93 & -7.03 & -56.42 \\
\hline \multirow{3}{*}{875} & $\sigma_{r e d}^{S}$ & 72.29 & 70.08 & 56.03 & 48.29 & 39.72 & 32.66 & 29.18 & 22.50 & 20.06 & 16,82 \\
\hline & $\sigma_{\text {red }}^{F}$ & 43.34 & 39.82 & 29.23 & 21.76 & 15.30 & 12.41 & 13.70 & 15.54 & 21.46 & 26.27 \\
\hline & ${ }^{*} \delta \sigma_{\text {red }} \%$ & 40.05 & 43.18 & 47.83 & 54.94 & 61.48 & 62.00 & 53.05 & 30.93 & -6.98 & -56.18 \\
\hline \multirow{3}{*}{1365} & $\sigma_{r e d}^{S}$ & 112.77 & 109.33 & 87.41 & 75.33 & 61.96 & 50.96 & 45.52 & 35.10 & 32.29 & 26.23 \\
\hline & $\sigma_{r e d}^{F}$ & 67.61 & 62.12 & 45.60 & 33.94 & 23.87 & 19.37 & 21.37 & 24.25 & 33.48 & 40.98 \\
\hline & ${ }^{*} \delta \sigma_{\text {red }} \%$ & 40.05 & 43.18 & 47.83 & 54.94 & 61.48 & 61.99 & 53.05 & 30.91 & -3.69 & $-56,23$ \\
\hline \multirow{3}{*}{1925} & $\sigma_{r e d}^{S}$ & 159.04 & 154.18 & 123.28 & 106,23 & 87.38 & 71.86 & 64.19 & 49.51 & 44.13 & 37.00 \\
\hline & $\sigma_{r e d}^{F}$ & 95.35 & 87.60 & 64.31 & 47.86 & 33.66 & 27.31 & 30.14 & 34.20 & 47.22 & 57.79 \\
\hline & ${ }^{*} \delta \sigma_{\text {red }} \%$ & 40.05 & 43.18 & 47.83 & 54.95 & 61.48 & 62.00 & 53.05 & 30.92 & -7.00 & -56.19 \\
\hline \multirow{3}{*}{2510} & $\sigma_{r e d}^{S}$ & 207.37 & 201.03 & 160.74 & 138.51 & 113.93 & 93.97 & 83.70 & 64.55 & 57.54 & 48.24 \\
\hline & $\sigma_{r e d}^{F}$ & 124.33 & 114.22 & 83.85 & 62.41 & 43.89 & 35.61 & 39.30 & 44.59 & 61.57 & 75.35 \\
\hline & ${ }^{*} \delta \sigma_{\text {red }} \%$ & 40.04 & 43.18 & 47.84 & 54.94 & 61.48 & 62.00 & 53.05 & 30.92 & -7.00 & -56.20 \\
\hline
\end{tabular}

However, based on numerical calculations using the finite element method (FEM), the results that were obtained could be compared. Table 3 presents the values of maximum reduced stresses $\sigma_{\text {red red }}$ in the zones of accumulated stresses for a circular axisymmetric perforated plate, free supported $\sigma_{\text {red max }}^{S}$ or fixed $\sigma_{\text {red max }}^{F}$ and loaded with concentrated force $P_{i}$ applied in the geometric center of the plate.

Table 3 The values of maximum reduced stresses $\sigma_{\text {red } \max }$ numerically determined.

\begin{tabular}{|c|c|c|c|c|c|c|c|c|c|c|c|}
\hline \multirow{2}{*}{$\begin{array}{c}P_{i} \\
{[\mathbf{N}]}\end{array}$} & \multirow{2}{*}{$\begin{array}{c}\sigma \\
{[\mathrm{MPa}]}\end{array}$} & \multicolumn{10}{|c|}{$\boldsymbol{R}_{n}[\mathrm{~mm}]$} \\
\hline & & 22,5 & 27,5 & 33,0 & 40,5 & 49,0 & 60,0 & 72,5 & 88,0 & 107,5 & 130,5 \\
\hline \multirow[t]{2}{*}{410} & $\sigma_{\text {red } \max }^{S}$ & 68.07 & 62.35 & 55.38 & 50.72 & 46.63 & 41.51 & 36.61 & 34.29 & 28.75 & 21.44 \\
\hline & $\sigma_{\text {red } \max }^{F}$ & 39.51 & 37.98 & 34.30 & 28.35 & 25.61 & 19.61 & 15.92 & 9.98 & 12.58 & 16.75 \\
\hline \multirow[t]{2}{*}{875} & $\sigma_{\text {red } \max }^{S}$ & 145.33 & 133.07 & 118.20 & 108.26 & 99.53 & 88.59 & 78.15 & 73.20 & 61.36 & 45.76 \\
\hline & $\sigma_{\text {red } \max }^{F}$ & 84.33 & 81.05 & 73.21 & 60.50 & 54.65 & 41.87 & 33.98 & 21.35 & 26.86 & 35.75 \\
\hline \multirow[t]{2}{*}{1365} & $\sigma_{\text {red } \max }^{S}$ & 226.72 & 207.59 & 184.39 & 168.88 & 155.27 & 138.20 & 121.91 & 114.19 & 95.72 & 71.39 \\
\hline & $\sigma_{\text {red } \max }^{F}$ & 131.56 & 126.44 & 114.20 & 94.38 & 85.25 & 65.31 & 53.01 & 33.25 & 41.90 & 55.77 \\
\hline \multirow[t]{2}{*}{1925} & $\sigma_{\text {red } \max }^{S}$ & 319.73 & 292.76 & 260.04 & 238.16 & 218.97 & 194.89 & 171.92 & 161.03 & 135.00 & 100.68 \\
\hline & $\sigma_{\text {red } \max }^{F}$ & 185.54 & 178.32 & 161.06 & 133.10 & 120.22 & 92.11 & 74.76 & 46.90 & 59.09 & 78.66 \\
\hline \multirow[t]{2}{*}{2510} & $\sigma_{\text {red } \max }^{S}$ & 416.79 & 381.73 & 339.06 & 310.54 & 285.51 & 254.12 & 224.17 & 209.97 & 176.02 & 131.28 \\
\hline & $\sigma_{\text {red } \max }^{F}$ & 241.90 & 232.51 & 210.00 & 173.55 & 156.76 & 120.10 & 97.48 & 61.15 & 77.05 & 102.56 \\
\hline
\end{tabular}

The boundary conditions of the perforated plate support have a significant influence on the distribution and values of stresses. The free support of the circular axisymmetric perforated plate on the whole circumference causes markedly increased values of the reduced stresses in relation to the perforated plate fixed on the entire circumference. In the case of free support of a circular axisymmetric perforated plate and loaded with a concentrated force $P_{i}$ applied in the geometric center of the plate in the first zone Z1 with the radius of the hole $d_{10}=20.5 \mathrm{~mm}$ and the radius of the circle on which the hole $R_{10}=130.5 \mathrm{~mm}$ is located. The reduced stress $\sigma_{\text {red }}$ was $\sigma_{\text {red } \max }=131.28 \mathrm{MPa}$ (Fig. 6a and Tab. 3) and in the tenth zone Z10 with the radius of the hole $d_{l}=3.5 \mathrm{~mm}$ and the radius of the circle on which the hole $R_{l}=22.5 \mathrm{~mm}$ is located (the nearest central part of the perforated plate) maximum value of the reduced stress $\sigma_{\text {red }}$ was $\sigma_{\text {red } \max }=$ 
416.79 $\mathrm{MPa}$ which is the most dangerous place in the plate (point with the coordinates $\mathrm{x}, \mathrm{y}, \mathrm{z}$ $[\mathrm{mm}]$, i.e. P10 [-69.9, 72.5; 0.0]), (Fig 6b and Tab. 3). However, in the case of fixed the perforated plate in the first zone Z1 with the radius of the hole $d_{10}=20.5 \mathrm{~mm}$ and the radius of the circle on which the hole $R_{10}=130.5 \mathrm{~mm}$ is located, the maximum value of the reduced stress $\sigma_{\text {red }}$ was $\sigma_{\text {red } \max }=102.56 \mathrm{MPa}$ (Fig. 8a and Tab. 3) and in the tenth zone Z10 with the radius of the hole $d_{1}=3.5 \mathrm{~mm}$ and the radius of the circle on which the hole $R_{1}=22.5 \mathrm{~mm}$ (the nearest central part of the perforated plate) the maximum value of the reduced stress $\sigma_{\text {red }}$ was $\sigma_{\text {red max }}=$ $241.90 \mathrm{MPa}$ which is the most dangerous place in the plate (point with coordinates $\mathrm{x}, \mathrm{y}, \mathrm{z}$ [mm], i.e. P10 [1.71, 23.0; 0.0), (Fig. 8b and Tab. 3). It follows from the above that not only the boundary conditions of the plate support have a significant influence on the distribution of stresses in the perforated plate, but also the diameter of the perforation hole. Significant values of reduced stress $\sigma_{\text {red }}$ are usually the cause of the formation of microcracks in the area of the perforation hole. In the case of variable (fatigue) loads, microcracks start to develop and, as a consequence, they may lead to the destruction of the machine element or the construction element in which the perforated element occurs. In connection with the above, it is very important to determine the value and location of stress concentration in machine components containing the reasons for their occurrence. Numerical calculation of circular axisymmetric perforated plates using the finite elements method ones allow to get an exact distribution stresses on the entire tested surface, especially in areas holes where there are significant stress gradients.

\section{CONCLUSION}

The following conclusions can be drawn from the above analysis:

1. The present study has demonstrated that the way a circular axisymmetric perforated plate is loaded and the diameter of perforation has a significant impact on the distribution of stresses on the entire surface of the plate, in particular in the area of holes and on the bridges between the holes;

2. The most hazardous place in a circular axisymmetric perforated plate, free supported and loaded with concentrated force $P_{i}$ applied in the geometric center of the plate with the highest stress concentration is located in zone $\mathrm{Z} 10$ with the hole radius $d_{1}=3.5 \mathrm{~mm}$ and the radius of the circle on which the hole $R_{1}=22.5 \mathrm{~mm}$ is located, the reduced stress is $\sigma_{\text {red } \max }=416.79 \mathrm{MPa}$ (point with the coordinates x,y,z [mm], i.e.. P10 [-69.9; 72.5; 0.0]), (Fig. 6b, zone Z10);

3. The most hazardous place in a circular axisymmetric perforated plate, fixed and loaded with concentrated force $P_{i}$ applied in the geometric center of the plate with the highest stress concentration is located in zone Z10 with the hole radius $d_{l}=3.5 \mathrm{~mm}$ and the radius of the circle on which the hole $R_{l}=22.5 \mathrm{~mm}$ is located, the reduced stress is $\sigma_{\text {red }}$ $\max =241.82 \mathrm{MPa}$ (point with the coordinates $\mathrm{x}, \mathrm{y}, \mathrm{z}[\mathrm{mm}]$, i.e.. P10 [1.71; 23.0; 0.0]), (Figure 8b, zone Z10);

4. Maximum relative disaggregations expressed in terms of the values of reduced stresses $\sigma_{\text {red }}$ obtained by the numerical method using the finite element method and the experimental method, in a circular axisymmetric perforated plate, with free edge support, did not exceed $33 \%$ in the present research.

5. The use of numerical methods (MES) leads to the development of topography of stress distribution over the entire surface of a perforated plate, in particular in the perforation holes area so as to offer details regarding the location of stress concentration zones. 


\section{REFERENCES}

[1] Chudzik, A., Świniarski, J. "Effect of changes in the thickness of a perforated plate of the heat exchanger on its structural stability", Journal of Theoretical and Applied Mechanics 42(2), pp. 325 - 334, 2004.

[2] Www.famet.com.pl 11.08.2018.

[3] Pástor, M., Čarák, P., Gomory, I. "The assessment of the residual stresses influence on generation of the infringement in shape-complex supporting members", Strojnícky časopis - Journal of Mechanical Engineering 69 (1), pp. 85 - 96, 2019. DOI: 10.2478/scjme-20190007

[4] Paška, Z., Fojtík, F., Ferfecki, P. "Full field evaluation of the stress tensor components in 2D photoelasticity via computer software", Strojnícky časopis - Journal of Mechanical Engineering 66 (2), pp. 63 - 66, 2016. DOI: 10.1515/scjme-2016-0019

[5] Bhattacharya, A., Venkat, R. "Peak stress multipliers for thin perforated plates with square arrays of circular hole", International Journal of Pressure Vessels and Piping 80, pp. $379-388,2003$.

[6] Bhattacharya, A., Venkat, R. "Yield Surfaces for Perforated Plates with Square Arrays of Holes", Nuclear Engineering and Design 231, pp. 219 - 233, 2004.

[7] Andh, U., Chavan, S., Kulkarni, S., Khurd, S. "Stress analysis of perforated plates under uniaxial compression using FEA and photoelasticity", International Research Journal of Engineering and Technology 3 (11), pp. 239 - 244, 2016.

[8] Andh, U., Chavan, S., Kulkarni, S. "Stress analysis of perforated plates under uniaxial compression using experimentation and finite element analysis", International Journal of Current Engineering and Technology 7 (2), pp. 431 - 437, 2017.

[9] Gasiak, G., Ledwoń, W. "Analiza numeryczna stanu naprężenia i ugięcia płyt perforowanych obciążonych siłą skupioną", Górnictwo odkrywkowe 55 (4), pp. 250 253, 2014. (in Polish).

[10] Achtelik, H., Gasiak, G., Grzelak, J. "Strength tests of axially symmetric perforated plates for chemical reactors: Part 1 - The simulation of stress state", International Journal of Pressure Vessels and Piping 85, pp. 248 - 256, 2008.

[11] Gomez, E., Ruiz, R., Wilson, R. "Asme section III stress analysis of a heat exchanger tubesheet with a misdrilled hole and irregular or thin ligaments", Proceedings of the ASME 2013 Pressure Vessels and Piping Conference 14 - 18 July, Paris, France, pp. 1 8, 2013.

[12] Achtelik, H., Gasiak, G., Grzelak, J. "Strength tests of axially symmetric perforated plates for chemical reactors: Part 2 - Experiments", International Journal of Pressure Vessels and Piping 85, pp. $257-264,2008$.

[13] Ledwoń, W., Achtelik, H. "Experimental Analysis of the State of Stress of the Axisymetric Perforated Plateds Loaded with Hydrostatic Pressure", Proceedings of the 13th International Scientific Conference, Computer Aided Engineering, Polanica Zdrój, pp. $331-341,2016$.

[14] El-Sawy, K. M., Nazmy, A. A., Mautini, M. J. "Elasto-plastic buckling of perforated plates uniaxial compression", Thin - Walled Structures 42, pp. 1083 - 1101, 2004.

[15] Minguez J. M., Vogwell, J. "Plater with holes under laternal load pressure", Engineering Failure Analysis 4, pp. 299 - 315, 1998. 
[16] Konieczny, M. "Numeryczna analiza stanu naprężenia w kołowosymetrycznej płycie z otworem centralntm przy dwóch wariantach obciążenia”, Zagadnienia Aktualnie Poruszane przez Młodych Naukowców 14 Kraków, 2019. ISBN: 978-83-63058-87-6 178-184 (in Polish).

[17] Konieczny, M., Gasiak, G. "State of Stress in the Plate with Slot at Biaxial Load", Conference Proceedings Fatigue Failure and Fracture Mechanics XXVII, 2018. ISSN: 978-0-7354-1750-2 1-9.

[18] Konieczny, M., Gasiak, G. "Research of maximum stresses zones in circular perforated plates made of S235JR steel loaded with concentrated force", Inżynieria Materiałowa Materials Engineering 2 (228), pp. 39 - 46, 2019.

[19] Konieczny, M., Achtelik, H., Gasiak, G. "Finite Element Analysis (FEA) and experimental stress analysis in circular perforated plates loaded with concentrated force", Frattura ed Integrità Strutturale 51, pp. 164 - 173, 2020.

[20] Real, M., Isoldi, L. A., Damas A. P., Helbig, D. "Elastic and elasto-plastic buckling analysis of perforated steel plates", Vetor 23 (2), pp. 61 - 70, 2013.

[21] Konieczny, M., Gasiak, G. "Badanie wpływu zamocowania kołowej płyty perforowanej na koncentrację naprężenia w warunkach działania ciśnienia hydrostatycznego", Zeszyty Naukowe Politechniki Rzeszowskiej - Scientific Letters of Rzeszow University of Technology 299 (1-2), pp. 41 - 52, 2019. (in Polish).

[22] Saraçoğlu, M., Albayrak, U. "Linear static analysis of perforated plates with round and staggered holes under their self-weights", Research of Engineering Structures and Materials 2 (1), pp. 39 - 47, 2016.

[23] Www.mesco.com.pl 15.04.2017.

[24] Jakubowicz, A., Orłoś, Z. "Wytrzymałość materiałów”, WNT Warszawa, 1984. (in Polish). 